\title{
KORELASI INDEKS MASSA TUBUH DENGAN FORMULA MODIFICATION OF DIET IN RENAL DISEASE PADA POPULASI SEHAT
}

\author{
Ima Septia, Rismawati Yaswir, Lillah, Efrida
}

\begin{abstract}
Abstrak
Penelitian ini bertujuan mengetahui korelasi indeks massa tubuh (IMT) dengan estimated Glomerular Filtration Rate (eGFR) berdasarkan formula MDRD pada populasi sehat di kota Padang. Penelitian analitik dengan rancangan potong lintang ini mengikutsertakan 121 orang peserta medical check up pada beberapa rumah sakit di Kota Padang pada bulan Agustus 2013Oktober 2014. Nilai eGFR dihitung menurut persamaan MDRD, kadar kreatinin diperiksa dengan metode enzimatik yang telah distandarisasi. Korelasi IMT dengan eGFR berdasarkan formula MDRD dianalisis menggunakan korelasi Pearson. Kemaknaan secara statistik ditentukan jika nilai $p<0,05$. Korelasi IMT dengan eGFR berdasarkan formula MDRD adalah korelasi negatif yang sangat lemah dan tidak bermakna $(r=-0,19 ; p>0,05)$. Simpulan: tidak didapatkan korelasi antara IMT dengan eGFR berdasarkan formula MDRD.
\end{abstract}

Kata kunci: eGFR, indeks massa tubuh, formula MDRD

\begin{abstract}
The purpose of this study was to evaluate the correlation between BMI and eGFR by MDRD formula among healthy population in Padang. This cross-sectional analytic study enrolled 121 participants taking medical check-up in several hospitals in Padang from August 2013 to October 2014. Value of eGFR was determined by MDRD formula, and a standardized enzimatic method was used for measuring creatinine levels. The correlation between BMI and eGFR by MDRD formula was analyzed using Pearson correlation. Statistical significancy was concluded if the value of $p<0.05$. The correlation of BMI and eGFR by MDRD formula was found very weak, negative, and not significant $(r=-0.19, p>0.05)$. Thus, there was no correlation between BMI and eGFR by MDRD formula.
\end{abstract}

Key words: eGFR, body mass index, MDRD formula

Afiliasi Penulis : Bagian Patologi Klinik Fakultas Kedokteran Universitas Andalas/ RSUP. Dr. M. Djamil Padang. Korespondensi: Ima Septia, Bagian Patologi Klinik Fakultas Kedokteran Universitas Andalas/ RSUP. Dr. M. Djamil Padang. Email: imaseptiagunawan@gmail.com. Telp/ Hp 081363411730 


\section{PENDAHULUAN}

Penilaian laju filtrasi glomerulus (LFG) dianggap sebagai indeks terbaik untuk menentukan fungsi ginjal karena penggunaan bersihan inulin sebagai ba$\mathrm{ku}$ emas memiliki banyak keterbatasan. ${ }^{1,2}$ Beberapa formula telah dikembangkan untuk menilai perkiraan LFG secara tidak langsung, yang paling luas digunakan adalah yang memakai kreatinin sebagai dasar perhitungannya. Formula tersebut dapat digunakan secara luas, mudah tetapi akurasinya cukup baik. ${ }^{3-5}$

Beberapa formula pengukuran GFR adalah persamaan menurut Cockcroft-Gault (CG), Modification of Diet in Renal Disease (MDRD), Chronic Kidney Disease Epidemiology Collaboration (CKD-EPI) dan Kidney Disease Outcomes Quality Initiative (KDOQI) untuk dewasa serta formula Schwartz dan Counahan-Barratt untuk anak. ${ }^{3,5}$

Formula MDRD telah direkomendasikan penggunaannya oleh National Kidney Foundation (NKF). ${ }^{1}$ Formula tersebut telah divalidasi oleh banyak penelitian pada berbagai usia, jenis kelamin, dan massa otot, akan tetapi validasinya masih terbatas pada populasi Afrika-Amerika dan Kaukasia, sedangkan populasi dari ras dan etnis lain terutama Asia dan Australia masih membutuhkan penelitian. ${ }^{1,6}$ Pengaruh ras dan etnis dinyatakan dalam persamaan sebagai koefisien etnis. Koefisien etnis yang sudah ada adalah untuk ras Kaukasia, Afrika-Amerika, Cina dan Jepang. 7,8

Ras yang berbeda memiliki massa otot yang berbeda, sehingga berpengaruh terhadap produksi kreatinin. Indeks massa tubuh dianggap dapat mencerminkan massa otot. Penelitian antropometrik pada populasi Minangkabau oleh Lipoeto dkk, tahun 2001 di Padang didapatkan IMT rerata adalah $23 \pm 0,4 \mathrm{~kg} / \mathrm{m} 2$. Suku Minangkabau merupakan populasi mayoritas di kota $\mathrm{Pa}-$ dang. ${ }^{9}$ Nilai ini lebih rendah diban- dingkan IMT Asia yaitu $27,6 \pm 5,5 \mathrm{~kg} / \mathrm{m}^{2} .{ }^{8}$ Subjek penelitian yang dianalisis untuk mendapatkan persamaan MDRD memiliki IMT yang lebih tinggi dibandingkan populasi Minangkabau yaitu $28 \pm 6$ $\mathrm{kg} / \mathrm{m}^{2}$ juga. ${ }^{6}$ Perbedaan ini kemungkinan berpengaruh terhadap nilai rerata kreatinin pada populasi normal yang akan berpengaruh terhadap nilai GFR individu sehat.

Pengukuran GFR menurut formula MDRD yang didapatkan sejak tahun 1999 dan ditinjau ulang pada tahun 2005 adalah dari perhitungan rumus berikut. ${ }^{1}$

$$
\begin{aligned}
& \text { GFR }\left(\mathrm{mL} / \mathrm{mn} / 1,73 \mathrm{~m}^{2}\right) \\
& =175,3(\mathrm{scr})^{-1,154} \times(\text { umur })^{-0,203} \times 0,742 \\
& \\
& \text { untuk perempuan, dan } \times 1,21 \text { untuk } \\
& \text { ras kulit hitam, (scr adalah kreatinin } \\
& \quad \text { serum) }
\end{aligned}
$$

Formula MDRD tidak direkomendasikan penggunaannya pada keadaan kadar kreatinin serum yang tidak stabil karena akan menghasilkan perkiraan fungsi ginjal yang tidak akurat. Keadaan tersebut adalah: usia kurang dari 18 tahun, massa otot dan diet yang ekstrim, perempuan hamil, kondisi komorbiditas berat dan gagal ginjal akut. ${ }^{1,10}$

Formula MDRD menggabungkan ras Afrika dan Amerika sebagai faktor untuk menghitung perbedaan metabolisme kreatinin pada populasi yang berbeda, sehingga akurasi formula tersebut lebih baik apabila dipakai untuk populasi ras Afrika dan Amerika. ${ }^{1,6}$ Akurasi yang lebih baik untuk pemakaian formula MDRD pada populasi diluar ras AfrikaAmerika membutuhkan faktor koreksi yang telah divalidasi, termasuk ras Asia. Ras dan etnis mempengaruhi perhitungan GFR karena ras yang berbeda juga memiliki perbedaan budaya dan kebiasaan termasuk pola makan yang berpengaruh terhadap metabolisme kreatinin. ${ }^{2,11}$

Pemakaian formula untuk memperkirakan GFR pada subjek nor- 
mal tanpa penyakit ginjal merupakan bidang yang perlu diteliti untuk mengetahui validitas suatu formula. ${ }^{1}$ Pengukuran GFR pada individu sehat dibutuhkan pada kondisi seleksi donor untuk transplantasi dan pada individu yang memiliki faktor risiko menderita CKD tetapi dengan GFR yang masih normal. ${ }^{5}$

\section{METODE}

Penelitian ini adalah penelitian analitik dengan rancangan potong lintang yang dilakukan di Laboratorium Patologi Klinik dan Poliklinik Umum RS. Dr. M. Djamil Padang dan beberapa rumah sakit swasta lain di Padang, mulai Agustus 2013 sampai Oktober 2014.

Populasi adalah semua orang yang datang untuk melakukan medical check up ke Poliklinik Umum RSUP. Dr. M. Djamil dan rumah sakit swasta lain di Padang. Sampel adalah bagian dari populasi yang memenuhi kriteria inklusi (berusia 18-40 tahun dan bersedia ikut serta dalam penelitian) dan eksklusi (riwayat hipertensi, diabetes melitus, penyakit ginjal yang diketahui dari anamnesis dan catatan medis, tekanan darah > 140/90 $\mathrm{mmHg}$, IMT < $17 \mathrm{~kg} / \mathrm{m}^{2}$, IMT > $30 \mathrm{~kg} / \mathrm{m}^{2}$, hamil, hemoglobin $<13$ $\mathrm{gr} / \mathrm{dL}$ (laki-laki) dan < $11 \mathrm{gr} / \mathrm{dL}$ (perempuan), leukosit $>12.000 / u L$, laju endap darah > $20 \mathrm{~mm} / \mathrm{jam}$, glukosa darah puasa > $126 \mathrm{mg} / \mathrm{dL}$, kreatinin serum $>1,17 \mathrm{mg} / \mathrm{dL}$ (laki-laki) dan $>0,95$ $\mathrm{mg} / \mathrm{dL}$ (perempuan), asam urat $>8,0$ $\mathrm{mg} / \mathrm{dL}$, proteinuria, glukosuria, leukosit urine $>5$ /LPB, eritrosit urine $>1$ /LPB. Besar sampel ditentukan dengan menggunakan rumus, didapatkan jumlah sampel minimal adalah 101,01 dibulatkan menjadi 102 orang. Penelitian ini telah disetujui oleh panitia etik penelitian BLU RSUP. Dr. M. Djamil Padang.

Bahan untuk pemeriksaan kimia klinik adalah serum setelah puasa 12 jam, untuk pemeriksaan hematologi whooleblood EDTA, dan untuk urinalisis rutin adalah $10 \mathrm{~mL}$ urine porsi tengah. Serum pasien yang memenuhi kriteria inklusi dan eksklusi diambil sisa serumnya dan dibagi menjadi aliquot kemudian disimpan pada suhu $-20^{\circ} \mathrm{C}$ untuk pemeriksaan kreatinin dalam analisis penghitungan eGFR (estimated GFR).

Pemeriksaan glukosa, kreatinin, dan asam urat menggunakan analyzer Cobas Integra (Roche Diagnostics). Pemeriksaan hemoglobin dan leukosit menggunakan hematology analyzer otomatis XT 2000i (Sysmex) dan pemeriksaan LED secara manual. Pemeriksaan urinalisis rutin menggunakan strip carik celup Dirui H 1000 dengan reader Dirui 500 dan pemeriksaan sedimen dikonfirmasi secara manual.

Kadar kreatinin diperiksa menggunakan metode enzimatik, hasil dinyatakan dalam $\mathrm{mg} / \mathrm{dL}$, dengan nilai rujukan 0,67-1,17 mg/dL (laki-laki) dan 0,51-0,95 $\mathrm{mg} / \mathrm{dL}$ (perempuan). Indeks massa tubuh didapatkan dari perhitungan berat badan $(\mathrm{kg}) /$ tinggi badan $\left(\mathrm{m}^{2}\right)$, kemudian dikelompokkan berdasarkan kategori IMT Depkes 2003. Perkiraan GFR menurut MDRD didapatkan dari perhitungan rumus: eGFR $\left(\mathrm{mL} / \mathrm{mn} / 1,73 \mathrm{~m}^{2}\right)=175$

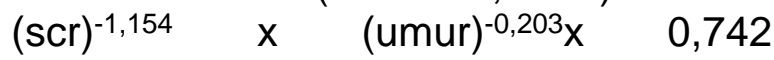
(perempuan).

Data hasil pemeriksaan diolah menggunakan piranti lunak SPSS versi 15.0. Analisis data meliputi analisis univariat yang dilakukan terhadap data karakteristik subyek penelitian dan analisis bivariat yang dilakukan untuk mengetahui korelasi IMT dengan eGFR berdasarkan formula MDRD. Uji korelasi Pearson digunakan untuk data parametrik, dan korelasi Spearman untuk data non parametrik. Kekuatan korelasi yang didapatkan ditetapkan sebagai berikut: sangat lemah, jika $r=0,00-0,19$; korelasi lemah, jika $r=0,20-0,39$; korelasi sedang, jika $r=0,40-0,59$; korelasi kuat, jika $r=0,60-0,79$; korelasi sangat kuat, jika $r=0,80-1,0$. 


\section{HASIL DAN PEMBAHASAN}

Tabel 1. berikut memperlihatkan karakteristik subyek penelitian. Subjek penelitian sebagian besar adalah lakilaki sebanyak 118 orang (97,5\%). Rerata umur adalah 33,92 tahun dalam rentang 22 tahun sampai 40 tahun. Indeks masa tubuh terbanyak adalah kategori gemuk sebanyak 47\%. Nilai rerata (SD) kadar kreatinin subjek penelitian adalah 0,56 $\mathrm{mg} / \mathrm{dL}(0,16 \mathrm{mg} / \mathrm{dL})$. Nilai eGFR berdasarkan formula MDRD subjek penelitian adalah 186,45 mL/min/1,73m². Uji normalitas Kolmolgorof Smirnof dilakukan terhadap IMT dan eGFR, dan didapatkan $p>0,05$ (berdistribusi normal) untuk IMT, dan $\mathrm{p}<0,05$ (tidak berdistribusi normal) untuk nilai eGFR menurut formula MDRD.

Tabel 1. Karakteristik Subjek Penelitian

\begin{tabular}{llc}
\hline $\begin{array}{c}\text { Karakteristik } \\
(\mathbf{n}=\mathbf{1 2 1})\end{array}$ & $\mathbf{f ( \% )}$ & Rerata (SD) \\
\hline $\begin{array}{c}\text { Jenis Kelamin } \\
\text { Laki-Laki } \\
(\mathrm{n}=118)\end{array}$ & 97,5 & \\
$\quad \begin{array}{l}\text { Perempuan } \\
(\mathrm{n}=3)\end{array}$ & 2,5 & \\
Umur (tahun) & & $33,92(4,74)$ \\
IMT (kg/m $\left.{ }^{2}\right)$ & & $23,90(2,78)$ \\
$\quad$ Normal $(\mathrm{n}=48)$ & 40 & $22,65(1,97)$ \\
$\quad$ Gemuk $(\mathrm{n}=54$ & 47 & $24,07(0,61)$ \\
$\quad$ Obes $(\mathrm{n}=19)$ & 13 & $27,97(0,78)$ \\
& & $0,56(0,16)$ \\
Kadar Kreatinin & & \\
$(\mathrm{mg} / \mathrm{dL})$ & & 186,45 \\
& & $(69,99)$ \\
\hline $\begin{array}{l}\text { Nilai eGFR } \\
\left(\mathrm{mL} / \mathrm{min} / 1,73 \mathrm{~m}^{2}\right)\end{array}$ & & \\
\hline
\end{tabular}

Nilai eGFR yang didapatkan pada penelitian ini lebih besar dibandingkan nilai rujukan normal GFR laki-laki dewasa sehat yaitu $125 \mathrm{~mL} / \mathrm{menit} / \mathrm{min} / 1,73 \mathrm{~m}^{2}$ yang dihitung berdasarkan bersihan inulin. ${ }^{12}$ Nilai ini juga lebih besar dibandingkan hasil penelitian Vervoot dkk, yang melakukan penelitian terhadap 23 subjek laki-laki sehat di Austria berumur 28,2 \pm 6,1 tahun, mendapatkan nilai eGFR sebesar $111 \pm 11 \mathrm{~mL} / \mathrm{min}$ $11,73 \mathrm{~m}^{2}$. Penelitian tersebut memakai rumus MDRD yang berbeda, yaitu: $170 \mathrm{x}$ (kadar kreatinin serum)-0,999) $\mathrm{x}$ (umur) $0,176 \mathrm{x}$ (kadar urea nitrogen serum) ( $0: 170 \mathrm{x}$ (kadar albumin serum) ${ }^{+0,318} \times 0,762$ jika perempuan $\times 180$ jika ras kulit hitam. ${ }^{13}$ Persamaan itu merupakaan persamaan awal MDRD yang pertama dikembangkan tahun 1999. Penelitian oleh Poggio dkk, mendapatkan persamaan MDRD menghasilkan nilai eGFR overestimated pada subjek sehat donor ginjal. ${ }^{13,14}$

Hal yang kemungkinan terkait dengan nilai eGFR yang sangat besar dari perhitungan menggunakan formula MDRD adalah perbedaan karakteristik subjek penelitian ini dengan subjek pada penelitian pengembangan formula MDRD, yang meliputi perbedaan populasi, perbedaan ras dan etnis, perbedaan metode pengukuran kreatinin, dan perbedaan umur.

Perbedaan pertama adalah pada penelitian ini subjeknya adalah subjek sehat sedangkan pada penelitian untuk formula MDRD subjeknya adalah populasi dengan CKD (chronic Kidney Disease) yang rerata nilai mGFR (measured GFR) $40 \mathrm{~mL} / \mathrm{min} / 1,73 \mathrm{~m}^{2}$.

Perbedaan kedua adalah ras subjek penelitian ini tidak termasuk ras subjek penelitian pengembangan formula MDRD. Formula MDRD dikembangkan dari penelitian dengan subjek ras Afrika dan Amerika. Berbagai penelitian pada ras diluar ras Afrika dan Amerika menyatakan pemakaian formula MDRD diluar ras Afrika dan Amerika memerlukan faktor koreksi dan koefisian yang berbeda untuk setiap ras, akan tetapi penelitian tentang hal tersebut masih terbatas. Penelitan faktor koefisien untuk ras terbatas pada populasi Jepang dan Cina sedangkan ras lain belum ada. ${ }^{15-17}$

Koefisien ras yang didapatkan selanjutnya digunakan untuk mendapatkan modifikasi persamaan eGFR untuk ras 
yang bersangkutan. Contohnya untuk ras Cina persamaan eGFR formula MDRD yang modifikasi untuk ras Cina menjadi eGFR $=175 \times$ (kreatinin serum) $1,234 \times$ (umur $^{-0,179} \times(0,79$ jika perempuan) dan untuk ras Jepang menjadi eGFR $=194 \times(\text { Kreatinin Serum })^{-1,094}$ $\times$ (umur $^{-0,287} \times(0,739$ jika perempuan $)$. Penelitian pada ras lain di Asia masih sebatas penilaian performance seperti pada populasi Malaysia, Korea, Asia Selatan, dan Singapara. ${ }^{15,16}$

Perbedaan ketiga yaitu perbedaan umur subjek penelitian. Rerata umur subjek penelitian ini adalah 33,89 $\pm 4,7$ tahun, sedangkan pada penelitian pengembangan formula MDRD mengikut seratakan semua subjek usia lebih dari 17 tahun. $^{6}$

Nilai eGFR berdasarkan formula MDRD yang sangat besar pada penelitian ini seharusnya dibuktikan dengan pemeriksaan mGFR menggunakan baku emas (inulin) atau baku perak (radio isotop) untuk mengetahui besarnya bias penggunaaan formula tersebut pada populasi sehat di penelitian ini.

Gambar 1 memperlihatkan korelasi IMT dengan eGFR berdasarkan formula MDRD dengan menggunakan uji korelasi Spearman. Korelasi negatif yang sangat lemah didapatkan dengan nilai $r=-0,19$ dan korelasi tersebut tidak bermakna secara statistik ( $p>0,05)$.

Subjek penelitian selanjutnya dibagi menjadi tiga kelompok berdasarkan IMT yaitu, kelompok dengan IMT normal, gemuk, dan obes. Korelasi IMT dengan eGFR selanjutnya dianalisis berdasarkan IMT subjek penelitian. Uji korelasi Pearson digunakan untuk mengetahui korelasi IMT dengan eGFR berdasarkan formula MDRD pada masing masing kelompok.

Gambar 2. memperlihatkan tidak terdapat korelasi antara IMT dengan eGFR menurut formula MDRD pada kelompok subjek dengan IMT kategori normal $(r=0,18, p>0,05)$.
Gambar 3 memperlihatkan tidak terdapat korelasi antara IMT dengan nilai eGFR menurut formula MDRD pada subjek dengan IMT gemuk $(r=-0,23$, $p>0,05)$.

Gambar 4. menunjukkan bahwa tidak terdapat korelasi IMT dengan nilai eGFR menurut formula MDRD pada kelompok subjek obes $(r=-0,24, p>0,05)$

Penelitian ini tidak mendapatkan korelasi antara IMT dengan eGFR MDRD. Hasil yang serupa didapatkan ketika analisis dilakukan pada subjek yang dikelompokkan berdasarkan kategori IMT.

Shaharudin dkk, mendapatkan hasil serupa dengan penelitian ini, ia tidak mendapatkan korelasi antara GFR 99mTc-DTPA dengan IMT $(p>0,05) .{ }^{18}$ Beberapa penelitian epidemiologi di Asia yang menyelidiki kaitan IMT dengan eGFR mendapatkan hasil yang tidak konsisten. Penelitian oleh Oh dkk, pada populasi Korea menyimpulkan bahwa tidak terdapat hubungan antara nilai IMT dengan penurunan eGFR berdasarkan formula MDRD dan CKD EPI, tetapi mendapatkan hubungan yang bermakna antara lingkar pinggang dengan penurunan fungsi ginjal. Kawamato dkk mendapatkan hasil yang serupa pada populasi Jepang ${ }^{8,19}$

Indeks massa tubuh merupakan rasio berat badan dengan tinggi badan kuadrat, yang sebenarnya lebih mencerminkan perbandingan tinggi badan dengan berat badan tetapi bukan komposisi tubuh. Indeks massa tubuh lebih tepat untuk menggambarkan kejadian obesitas dibandingkan massa otot. Seseorang dengan massa otot besar seperti atlet dapat saja memiliki IMT yang sama dengan seseorang yang mengalami obesitas, sedangkan kreatinin tergantung kepada massa otot. ${ }^{20,} 21$

Penentuan komposisi tubuh secara antropometri yang lebih mencerminkan massa otot yang berarti sebanding dengan produksi kreatinin adalah dengan mengukur triceps skin 
fold (TSF) yaitu ketebalan otot trisep dan arm sircumferance (AC) atau lingkar lengan, kemudian menghitung menggunakan persamaan: $\{[(\mathrm{AC}-\Pi \times \mathrm{TSF})] 4 \Pi$ $X 2\}-10$.

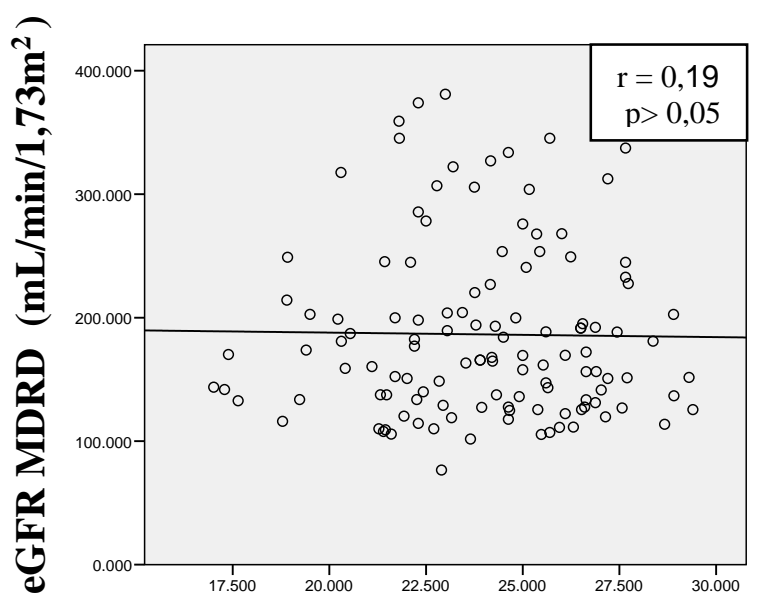

IMT $\left(\mathrm{Kg} / \mathrm{m}^{2}\right)$

\section{Gambar 1. Korelasi IMT dengan eGFR berdasarkan formula MDRD}

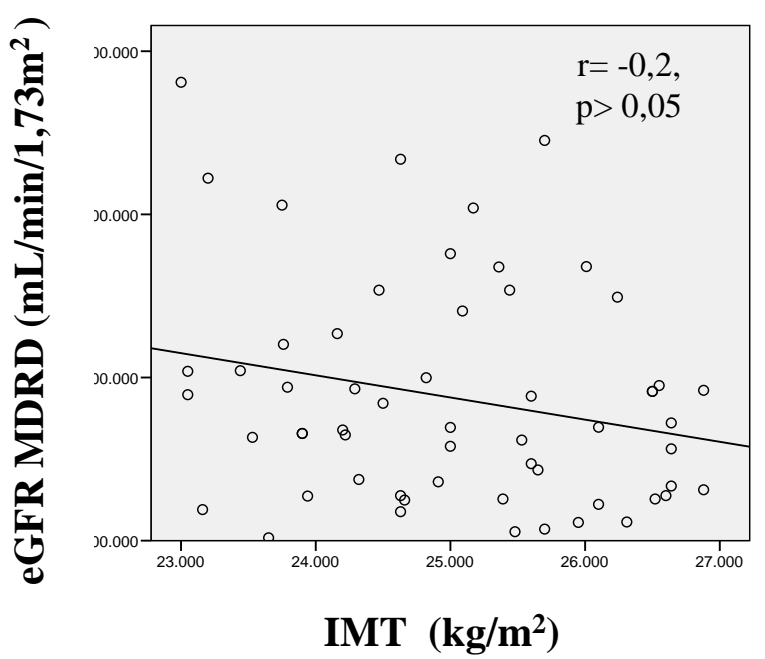

Gambar 3. Korelasi IMT Gemuk dengan eGFR berdasarkan Formula MDRD

\section{SIMPULAN}

Kesimpulan yang didapatkan dari penelitian ini adalah tidak terdapat korelasi antara IMT dengan eGFR
Pemeriksaan yang lebih realibel adalah dengan dual $x$ ray absorbtiometri, computer tomographi, dan magnetig resonance imaging. ${ }^{20}$
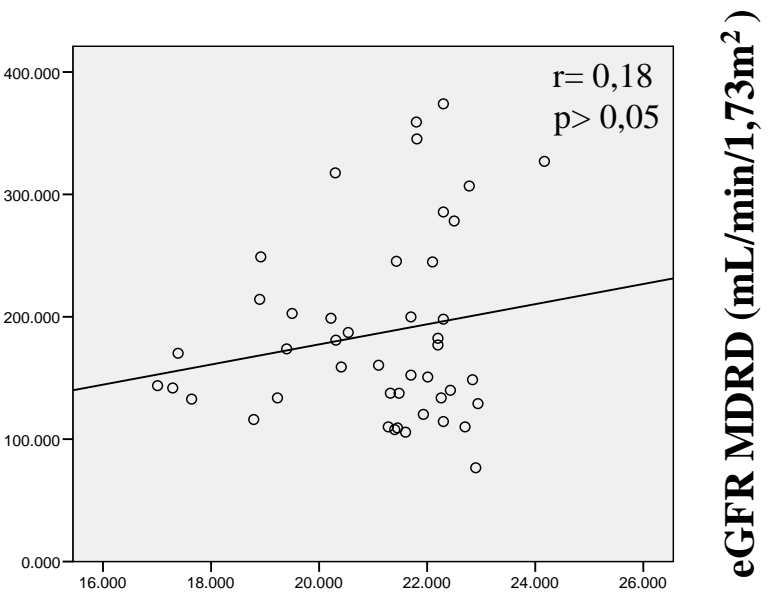

Gambar 2. Korelasi IMT Normal dengan eGFR Berdasarkan Formula MDRD
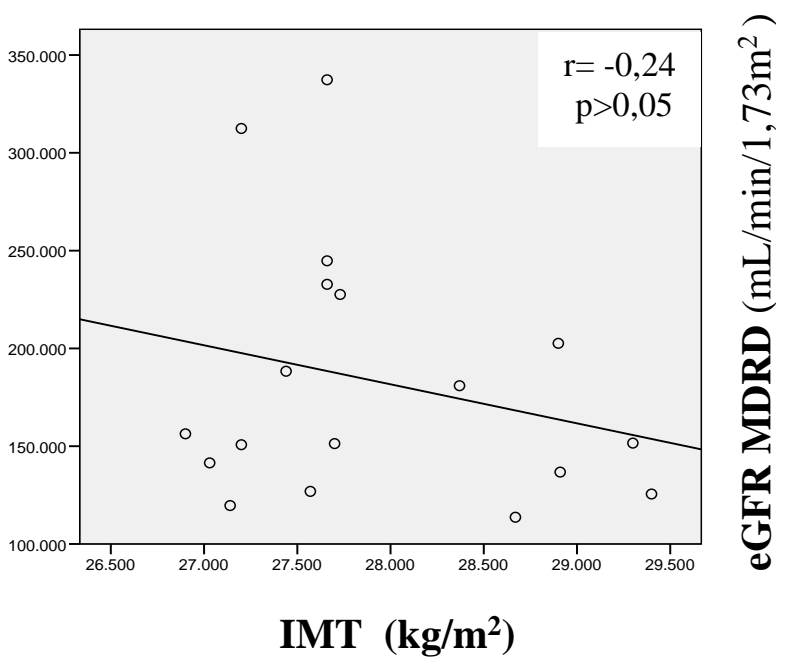

Gambar 4. Korelasi IMT Obes dengan eGFR Berdasarkan Formula MDRD

berdasarkan formula MDRD pada populasi sehat yang melakukan medical check up di beberapa rumah sakit di kota Padang. 


\section{DAFTAR RUJUKAN}

1. National Kidney Foundation. Frequently Asked-Question About GFR Estimates. 2011 [diunduh tanggal 21 Oktober 2013]. Diakses dari http://www.Kidney.org

2. Lamb E, Newman DJ, and Price CP. Kidney Function Test. In: Burtis CA, Ashwood ER, Bruns DE, Editors. Tietz Textbook Of Clinical Chemistry And Molecular Diagnostic 4 th ed. Missouri: Elsevier Sauders; 2006.p.797-828.

3. Munikrishnappa D. Chapter 6 Geriatric Nephrology Curriculum: Limitations of Various Formulae and Other ways of Assessing GFR In the Elderly: Is There A Role for Cystatin C? American Society of Nephrology; 2009.p. 1-7.

4. Israni $\mathrm{AK}$ and Kasiske BL. Laboratory Assessment of Kidney Disease: Glomerular Filtration Rate, Urynalisis, and Protein-uria. In: Brenner, Rector, and Apos, Editors. Kidney 9 thed. Elsevier; 2012.p.868-96.

5. Lascano ME \& Pogio ED. Kidney Function Assessment by Creatinine-Based Estimation Equations. 2010 [diunduh tanggal 2 September 2013]. Diakses dari http://www.Clevelandclinicmeded.Com,

6. Levey AS, Stevens LA, Schmid CH, Zhang $\mathrm{Y}$, Castro AF, Feldman $\mathrm{HI}$ et al. CKD-EPI (Chronic Kidney Disease Epidemiology Collaboration) A New Equation To Estimate Glomerular Filtration Rate. Ann Intern Med. 2009;50(9):604-12.

7. Jiang-Tao L, Chun-li C, Hui-fang W, Yi-tai W, Xiao-fung J, Jun $M$. Relative Performance Of Two Equations For Estimation Of Glomerular Filtration Rate In A Chinese Population Having Chronic Kidney Disease. Chin Med J (Engl). 2012 Feb;125(4):599-603.

8. Kawamoto R, Kohara K, Tabara Y, Miki $\mathrm{T}$, Ohtsuka $\mathrm{N}$, Kusunoki $\mathrm{T}$, et al. An Association Between Body Mass Index And Estimated Glomerular Filtration Rate. Hypertens Re. 2008;31:1559-64.

9. Lipoeto NI. Minangkabau Traditional Diet And Cardiovascular Disease Risk In West Sumatra, Indonesia. A Thesis Submitted For The Degree Of Doctor Of Philosophy. International Health And Development Unit. Faculty Of Medicine, Nursing And Health Sciences. Monash University Melbourne, Australia. 2001.

10. Rule AD. The CKD-EPI Equation for Estimating GFR Serum Creatinine: Real
Improvement or More of the Same. Clin J Am Soc Nephrol. 2010;5:951-3.

11. Oh H. Evaluation of Renal Function, Water, Electrolytes Balance and Acid-Base Balance. In: McPersoan MA and Pincus M, Editors. Henry's Clinical Diagnosis and Management by Laboratory Methods $21^{\text {th }}$ ed chapter14, Elsevier; 2007.p.147-55.

12. Guyton $A C$ and Hall JE. Urine Formation by The Kidney. In Text Book of Medical Phisiology, Chapt 26. Philadelphia: Elsevier Saunders Company; 2006.p.1618.

13. Vervoot $G$, Willems HL, Wetzels JFM. Assessment of glomerular filtration rate in healthy subjects and ormoalbuminuric diabetic patients: validity of a new (MDRD) prediction equation. Nephrol Dial Transplant. 2002;17:1909-13.

14. Poggio ED, Wang X, Greene T, Lente FV and Hall $\mathrm{PH}$. Performance of the Modification of Diet in Renal Disease and Cockcroft-Gault Equations in the Estimation of GFR in Health and in Chronic Kidney Disease. J Am Soc Nephrol. 2005;2:459-66.

15. Stevens LA, Coresh J, Greene T, and Levey AS. Assessing Kidney Function Measured and Estimated Glomerular Filtration Rate. N Engl J Med. 2006;354:2473-83.

16. Ma Y, Zuo L, Chen JH, Luo Q, Yu XQ, Li $\mathrm{Y}, \mathrm{Xu}$ JS et al., Modified Glomerular Filtration Rate Estimating Equotion for Chinese Patients with Chronic Kidney Disease. J Am Soc Nephrol. 2006;17:2937-45.

17. Rule AD and Teo BW GFR. Estimation in Japan and China: What Accounts for theDifference?. Am J Kidney Dis. 2009 June;53(6):932-5.

18. ShaharudinNH, Gafor AHA, Zainudin s, Kong NCT1, Aziz AA, Shah SA, Estimating Glomerular Filtration Rate in Overweight and Obese Malaysian Subjects. Int J Nephrol Urol. 2011;3(1):152.

19. Oh H, Quan SA, Jeong JY, Jang SN, Lee JE, Kim DH. Waist circumference, not body mass index, is associated with renal function decline in korean population: hallym aging study. PLoSOne. 2013;8(3):e59071.

20. Nakao T, Kanazawa $Y$, Nagaoka $Y$, Iwasawa $H$. Body protein index based on 
bioelectricalimpedance analysis is a useful newmarker assessing nutritional status: applications to patients with chronic renal failure on maintenance dialysis. In Suzuki H, Kimmel PL, Editors. Nutrition and kidney disease a new era basel karger. Contrib Nephrol. 2007;155:18-28.
21. Wells JC K and Fewtrell MS. Measuring body composition. Arch Dis Child. 2006;91:612-7. 